\title{
PERAN UMKM (USAHA MIKRO KECIL MENENGAH) DALAM MENINGKATKAN KESEJAHTERAAN MASYARAKAT
}

\author{
Kadeni $^{1)}$, Ninik Srijani ${ }^{2)}$ \\ STKIP PGRI Blitar ${ }^{1}$, Universitas PGRI Madiun ${ }^{2}$ \\ denikdk@gmail.com,ninikikipae@gmail.com
}

\begin{abstract}
The purpose of this literature study discussion is to illustrate the role of MSMEs (micro small and medium enterprises) in improving the welfare of the community. To discuss this problem using the literature study method. The results of the discussion show that the role of micro, small and medium enterprises is very important to improve the community's economy. This business was chosen because it has been proven tested in dealing with any situation including the monetary crisis and its major role in equalizing income and the welfare of the community.
\end{abstract}

Keywords: small, micro and medium enterprises, welfare

\begin{abstract}
Abstrak
Tujuan dari pembahasan studi kepustakaan ini untuk menggambarkan peran UMKM (usaha mikro kecil menengah) dalam meningkatkan kesejahteraan masyarakat. Untuk membahas masalah ini menggunakan metode studi kepustakaan. Hasil pembahasan menunjukkan bahwa keberadaan usaha mikro, kecil dan menengah perannya sangat penting untuk meningkatkan ekonomi masyarakat. Usaha ini dipilih karena sudah terbukti teruji dalam menghadapi situasi apapun termasuk krisis moneter dan besar perannya dalam memeratakan pendapatan dan mensejahterakan masyarakat.
\end{abstract}

Kata kunci: usaha kecil, mikro dan menengah, kesejahteraan 


\section{PENDAHULUAN}

Kehidupan yang sejahtera menjadi dambaan setiap orang untuk memenuhi hasrat ekonominya berupa segala kebutuhan baik sandang, pangan dan papan dalam menjalani kehidupan sehari-harinya. Upaya yang dilakukan agar tujuan tercapai masyarakat akan terus berusaha melakukan berbagai usaha. Upaya yang dapat ditempuh yaitu dengan mendirikan usaha mikro, kecil, dan menengah (UMKM). UMKM merupakan salah satu jenis usaha kecil yang sangat berperan dalam peningkatan dan pertumbuhan perekonomian masyarakat. Karena keberadaan UMKM mampu bertahan dalam situasi apapun untuk tercapainya kesejahteraan masyarakat. Ketangguhan UMKM terbukti saat terjadi krisis moneter tahun 1998 banyak usaha-usaha besar yang berjatuhan namun UMKM tetap bertahan dan bahkan bertambah jumlahnya.

Dengan begitu besarnya andil UMKM dalam menopang perekonomian suatu negara sehingga keberadaan UMKM sangat diharapkan oleh suatu negara manapun karena perannya yang vital dalam perkembangan dan kemajuan perekonomian untuk mencapai kesejahteraan masyarakat. Berdirinya usaha di sektor UMKM mampu menyerap jumlah angkatan kerja yang siap bekerja tetapi belum mendapat pekerjaan sehingga dapat mengurangi jumlah pengangguran. Berkembangnya partumbuhan di sektor usaha mikro semakin terbukanya kesempatan peluang kerja dan pada gilirannya akan meningkatkan pendapatan masyarakat.

Dengan berkurangnya jumlah pengangguran berarti sektor UMKM banyak merekrut tenaga kerja yang berarti akan membantu pemerintah dalam upaya mengurangi angka kemiskinan. Peran usaha mikro, kecil, dan menengah (UMKM) membantu meningkatkan angka pertumbuhan ekonomi dan mampu menyerap jumlah tenaga kerja dan distribusi hasil-hasil pembangunan dapat meningkatkan dirasakan oleh masyarakat.
Akibat dari badai krisis ekonomi di negara kita yang terjadi dalam beberapa waktu lalu, berdampak pada banyak usaha besar mengalami perlambatan pertumbuhan bahkan berhenti aktifitasnya.

Sementara di sektor usaha mikro kecil dan menengah terbukti tetap survive dan tetap hidup dalam menghadapi krisis ekonomi. Berdasarkan pengalaman selama krisis yang telah terjadi Indonesia tersebut, sudah sewajarnya jika pengembangan perekonomian di sektor swasta difokuskan pada pengembangan UMKM. Secara umum, UMKM dalam perekonomian memiliki peran sebagai: (1) pemeran utama dalam kegiatan perekonomian, (2) penyedia lapangan kerja, (3) pemain penting dalam pengembangan perekonomian lokal dan pemberdayaan masyarakat, (4) pencipta pasar baru dan sumber inovasi, (5) kontribusinya terhadap neraca pembayaran. (Departemen Koperasi, 2008).

Bertolak dari kelima peran tersebut, maka pengembangan UMKM harus dilakukan dengan terencana, terstruktur serta secara berkelanjutan, dengan arah peningkatan produktivitas dan daya saing, serta dapat terus menumbuhkan wirausahawan-wirausahawan baru yang lebih tangguh sehingga mampu meningkatkan kesejahteraan masyarakat. Keberadaan UMKM di Indonesia terus mengalami perkembangan dan terus bertambah. Berdasarkan data dari Departemen Koperasi dan UMKM dilihat dari jumlah unitnya tahun 2016 sebanyak 61.656 .547 meningkat menjadi 62.926.077 di tahun 2017 atau naik 2,06\%. Kenaikan jumlah unit tersebut juga berdampak pada meningkatnya jumlah tenaga kerja yang diserap oleh UMKM dari tahun 2016 mampu menampung 112.828.610 orang dan di tahun 2017 menjadi 116.673.416 atau meningkat sebesar 3,41\%. Hal tersebut menunjukkan bahwa keberadaan UMKM mampu meningkatkan kesejahteraan masyarakat. 


\section{METODE PENELITIAN}

Metode penelitian yang dipergunakan adalah metode studi pustaka, yaitu serangkaian kegiatan yang berkaitan dengan metode pengumpulan data pustaka, membaca, mencatat serta mengolah bahan penelitian (Zed, 2003). Empat ciri utama dalam penelitian studi pustaka yaitu : Pertama, bahwa peneliti berhadapan langsung dengan teks (naskah) atau data angka, bukan dengan pengetahuan langsung dari lapangan. Kedua, data pustaka bersifat "siap pakai" artinya peneliti tidak terjun langsung ke lapangan karena peneliti berhadapan langsung dengan sumber data yang ada di perpustakaan. Ketiga, bahwa data pustaka pada umumnya merupakan sumber sekunder, dalam arti bahwa peneliti memperoleh bahan atau data dari tangan kedua dan bukan data orisinil dari data pertama di lapangan. Keempat, bahwa kondisi data pustaka tidak dibatasi oleh ruang dan waktu. Berdasarkan dengan hal tersebut di atas, maka pengumpulan data dalam penelitian dilakukan dengan cara menelaah dan/atau mengembangkan beberapa bahan pustaka seperti jurnal, buku, dan dokumen-dokumen (baik yang berbentuk cetak maupun elektronik) serta sumber-sumber data dan atau informasi lainnya yang dianggap relevan dengan penelitian atau kajian.

\section{HASIL DAN PEMBAHASAN}

\section{Usaha Mikro Kecil dan Menengah (UMKM)}

Menurut Undang-Undang Republik Indonesia No. 20 Tahun 2008 tentang UMKM. Pasal 1, dinyatakan usaha mikro adalah usaha produktif milik orang perorangan dan/atau badan usaha perorangan yang memiliki kriteria usaha mikro sebagaimana diatur dalam UU tersebut. Usaha kecil merupakan suatu usaha ekonomi produktif yang berdiri sendiri, yang dilakukan oleh orang perorangan atau badan usaha yang bukan merupakan anak perusahaan atau bukan anak cabang yang dimiliki, dikuasai atau menjadi bagian, baik langsung maupun tidak langsung, dari usaha menengah atau usaha besar yang memenuhi kriteria usaha kecil sebagaimana dimaksud dalam UU tersebut.

Beberapa kriteria yang digunakan dalam Undang-undang tersebut untuk mendefinisikan UMKM yang tercantum di dalam Pasal 6 adalah nilai kekayaan bersih atau nilai aset tidak termasuk tanah dan bangunan tempat usaha, atau hasil penjualan tahunan. Dengan kriteria sebagai berikut : a. Usaha mikro adalah unit usaha yang memiliki aset paling banyak Rp. 50 juta dan tidak termasuk di dalamnya tanah dan bangunan tempat usaha dengan hasil penjualan per tahun paling besar Rp. 300 juta. b. Usaha kecil dengan nilai aset lebih dari Rp. 50 juta sampai dengan paling banyak Rp. 500 juta tidak termasuk tanah dan bangunan tempat usaha memiliki hasil penjualan per tahun lebih dari Rp. 300 juta hingga maksimum Rp. 2.500.000,00, dan. c. Usaha menengah adalah suatu perusahaan yang nilai kekayaan bersihnya lebih dari Rp. 500 juta dan paling banyak mencapai Rp.100 milyar dan hasil penjualannya per tahun mencapai di atas Rp. 2,5 milyar dan paling tinggi mencapai Rp. 50 milyar. Untuk menentukan di samping nilai moneter yang digunakan sebagai kriteria, beberapa lembaga pemerintah seperti Departemen Perindustrian dan Badan Pusat Statistik (BPS), selama ini jumlah pekerja yang dipakai sebagai ukuran untuk mengklasifikasikan suatu usaha masuk sebagai usaha mikro, usaha kecil, usaha menengah dan usaha besar.

Menurut Badan Pusat Statistik (BPS), usaha mikro merupakan suatu unit usaha yang jumlah pekerja tetapnya hingga 4 orang, untuk usaha kecil pekerja tetapnya antara 5 sampai 19 orang, dan usaha menengah jumlah pekerja tetapnya dari 20 hingga 99 orang. Perusahaan-perusahaan dengan jumlah pekerja di atas 99 orang masuk dalam kategori 
usaha besar. Pentingnya keberadaan usaha mikro kecil dan menengah dalam kancah perekonomian nasional tidak hanya karena jumlahnya yang banyak, tetapi juga dalam hal banyaknya kemampuan menyerap tenaga kerja.

Selain itu usaha berskala mikro, kecil dan menengah juga mampu melakukan kegiatan ekspor barang-barang tertentu yang mampu menghasilkan jumlah devisa yang cukup besar sehingga mampu menyumbang kontribusi terhadap Product Domestic Bruto (PDB). Secara umum, tujuan atau sasaran yang ingin dicapai adalah terwujudnya Usaha Mikro, Kecil dan Menengah (UMKM) yang tangguh dan mandiri yang memiliki daya saing tinggi dan berperan utama dalam produksi dan distribusi kebutuhan pokok, bahan baku, serta dalam permodalan untuk menghadapi persaingan bebas.

\section{Klasifikasi Usaha Mikro Kecil dan Menengah}

Berikut ini adalah klasifikasi Usaha Mikro Kecil dan Menengah : a. Livelhood Activities, merupakan usaha berskala mikro kecil dan menengah yang mampu membuka peluang kesempatan kerja untuk mendapatkan penghasilan, yang lebih umum biasa disebut sektor informal, seperti pedagang kaki lima. b. Micro Enterprise, yaitu suatu usaha mikro kecil dan menengah yang mempunyai sifat-sifat sebagai pengrajin namun belum mempunyai sifat-sifat kewirausahaan. c. Small Dynamic Enterprise, yaitu sebuah usaha mikro kecil dan menengah yang telah mempunyai jiwa kewirausahaan serta mampu untuk menerima pekerjaan subkontrak dan ekspor. d. Fast Moving Enterprise, merupakan usaha mikro kecil dan menengah yang telah mempunyai jiwa wirausaha dan pelaku usaha akan melakukan pengembangan atau transformasi menjadi usaha berskala besar (UB).

\section{Ciri-Ciri Usaha Mikro, Kecil, dan Menengah}

Terdapat beberapa ciri usaha mikro, kecil, dan menengah, yaitu : a. Jenis komoditi yang diusahakan tidak tetap dan bisa berganti sewaktu-waktu; b. Tempat menjalankan usahanya sewaktu-waktu bisa berpindah; c. Belum menerapkan kegiatan administrasi dalam menjalankan usahanya, bahkan seringkali tidak bisa membedakan keperluan keuangan untuk pribadi maupun keuangan usaha; d. Sumber daya manusia (SDM) di dalamnya belum punya jiwa wirausaha yang mumpuni; e. Biasanya tingkat pendidikan SDM nya masih rendah; f. Para pelaku UMKM biasanya belum mempunyai jaringan perbankan, akan tetapi sebagian dari mereka telah mempunyai jaringan ke Lembagalembaga keuangan bukan bank; g. Umumnya para pelaku usaha kecil belum mendapatkan bukti legalitas atau surat ijin usaha, seperti nomor pokok wajib pajak (NPWP).

\section{Karakteristik UMKM}

Karakteristik dari usaha mikro, kecil dan menengah adalah bersifat faktual dan melekat dalam menjalankan kegiatan usahanya maupun perilaku pengusaha itu sendiri. Karakteristik tersebut menjadi ciri yang membedakan antar pelaku usaha sesuai dengan skala usahanya. Bank Dunia mengelompokkan UMKM menjadi tiga jenis, yaitu: 1. Usaha Mikro yaitu usaha yang mempekerjakan karyawan 10 orang); 2. Usaha Kecil yaitu usaha yang mempekerjakan karyawan 30 orang); dan 3. Usaha Menengah yaitu usaha yang mempekerjakan karyawan hingga 300 orang).

Dalam perspektif usaha menurut Bank Indonesia (2015) UMKM dibagi menjadi empat kelompok, yaitu: 1. UMKM Mikro adalah para pelaku UMKM yang memiliki kemampuan sifat pengrajin termasuk di dalamnya UMKM sektor informal, seperti pedagang kaki lima yang kurang mampu mengembangkan usahanya karena mereka kurang mempunyai jiwa kewirausahaan. 2. Usaha Kecil Dinamis merupakan suatu kelompok UMKM yang mampu menjadi 
wirausahawan dengan menjalin kerjasama (menerima pekerjaan subkontrak) dan ekspor. 3. Fast Moving Enterprise adalah UMKM yang cakap dan telah siap mengembangkan usahanya menjadi usaha besar karena telah mempunyaijiwa kewirausahaan.

\section{Manfaat UMKM}

Penyumbang Terbesar Produk Domestic

Manfaat bisnis sektor UMKM adalah meningkatnya produk yang dihasilkan oleh dalam negeri. Produk-produk yang ada tidak hanya akan merambah pasar nasional saja tapi juga produk dalam negeri bisa merambah pasar internasional. Produk lokal banyak diminati oleh banyak orang. Contohnya produk kerajinan. Produk kerajinan dari Indonesia juga banyak yang terkenal sampai di luar negeri.

\section{Terbukanya Lapangan Pekerjaan}

Tidak dapat disangkal lagi bahwa sektor UMKM secara tidak langsung membuka peluang bagi orang-orang untuk mendapatkan pekerjaan. Hal ini bisa membantu pemerintah mengurangi jumlah angka pengangguran yang ada.

\section{Solusi Masyarakat Kelas Menengah}

Modal yang diperlukan untuk membuka usaha dalam sektor UKM ini tidaklah susah. Bisa dikatakan mudah. Banyak sudah lembaga pemerintah yang membantu untuk memberikan bantuan dana modal dengan jumlah nilai kredit yang kecil. Saat ini bank juga memberikan jaminan pinjaman modal dengan nilai perkreditan yang kecil.

\section{Operasional yang Fleksibel}

Struktur kepemimpinan dalam sektor UMKM relatif tidak besar. Setiap kepemimpinan mempunyai wewenang dan tanggung jawab masing-masing. Tidak hanya itu biasanya untuk bisnis sektor UMKM lebih cenderung memikirkan selera konsumen dan trend yang berkembang saat ini.

\section{Kekuatan dan Kelemahan UMKM}

UMKM mempunyai beberapa kekuatan potensial yang mampu menjadi pusat pengembangan usaha di masa mendatang yaitu : a. Penyedia lapangan kerja di sektor usaha industri kecil yang mampu menyerap tenaga kerja hingga 50\% tenaga kerja yang tersedia; b. Keberadaan usaha kecil dan menengah selama ini terbukti mampu menciptakan wirausaha baru yang dapat membangkitkan tumbuh dan berkembangnya wirausaha baru; c. Mempunyai bagian sendiri usaha pasar yang unik, menggunakan manajemen yang sederhana dan fleksibel dari kemungkinan perubahan pasar; d. Mampu diberdayakannya sumber daya alam yang ada di sekitar, industri kecil sebagian besar dapat memanfaatkan limbah atau hasil sampai dari industri besar atau industri yang lainnya, e. Memiliki potensi untuk berkembang.

Kelemahan, yang sering juga menjadi faktor penghambat dan permasalahan dari Usaha Mikro terdiri dari 2 faktor : 1) Faktor Internal Faktor internal, merupakan masalah yang sering dihadapi oleh UMKM yaitu: a) Masih terbatasnya kemampuan sumber daya manusia. b) Terbatasnya area pemasaran produk yang sebagian besar dari pengusaha Industri Kecil lebih mengutamakan pada aspek produksi sedangkan untuk fungsifungsi pemasaran kurang mempunyai kemampuan dalam mengaksesnya, khususnya dalam memperoleh informasi pasar dan jaringan pasar, sebagai konsekuensinya sebagian besar dari mereka hanya sebagai tukang saja. c) Konsumen cenderung belum mempercayai kualitas produk industri kecil. d) Kendala yang sering dihadapi adalah masalah permodalan usaha dari sebagian besar industri kecil memanfaatkan modal sendiri yang jumlahnya relatif kecil. Faktor eksternal, merupakan masalah yang ditimbulkan oleh pihak pengembang dan pembina UMKM. Misalnya usulan pemecahan masalah yang diberikan tidak tepat sasaran dan seringkali monitoringnya tidak dilakukan dan program yang tumpang tindih. 
Dari kedua faktor tersebut muncullah kesenjangan di antara faktor internal dan eksternal, yaitu di sisi perbankan, BUMN dan lembaga pendamping lainnya sudah siap dengan pemberian kredit, tapi UMKM mana yang diberi, karena berbagai ketentuan yang harus dipenuhi oleh UMKM.

Di sisi lain UMKM juga mengalami kesulitan mencari dan menentukan lembaga mana yang dapat membantu dengan keterbatasan yang mereka miliki dan kondisi ini ternyata masih berlangsung meskipun berbagai usaha telah diupayakan untuk memudahkan bagi para pelaku UMKM memperoleh kredit, dan ini telah berlangsung 20 tahun. Pola yang ada sekarang adalah masing-masing lembaga/institusi yang memiliki fungsi yang sama tidak berkoordinasi tapi berjalan sendiri-sendiri, apakah itu perbankan, BUMN, departemen, LSM, perusahaan swasta. Di samping dengan keterbatasannya UMKM menjadi penopang perekonomian menjadi roda perekonomian menjadi kenyataan.

\section{Kesejahteraan Masyarakat}

Kesejahteraan merupakan titik ukur bagi suatu masyarakat telah berada pada kondisi sejahtera. Kesejahteraan merupakan persamaan hidup yang setingkat lebih tinggi dari kehidupan sebelumnya. Perasaan senang, tidak kurang suatu apapun dalam batas yang mungkin dicapainya, ia terlepas dari kemiskinan serta bahaya yang mengancam adalah ciri-ciri seseorang yang hidupnya sejahtera.

Kesejahteraan adalah standard living, well-being, welfare, dan quality of life. Undang-undang No. 11 Tahun 2009, tentang Kesejahteraan Masyarakat, kesejahteraan masyarakat diartikan kondisi telah terpenuhinya kebutuhan material, spiritual, dan sosial warga negara agar dapat hidup layak dan mampu mengembangkan diri, sehingga dapat melaksanakan fungsi sosialnya. Berdasarkan undang-undang tersebut dapat diketahui bahwa tingkat kesejahteraan dapat diukur dan dinilai berdasarkan atas kemampuan dari seorang individu atau kelompok di dalam usahanya untuk memenuhi kebutuhan baik material maupun spiritualnya.

Kesejahteraan tidak dapat didefinisikan hanya berdasarkan konsep material dan hedonis, tetapi juga memasuki tujuan-tujuan kemanusiaan dan kerohanian. Sehingga konsep kesejahteraan tidak hanya mendasarkan telah terpenuhinya kebutuhan material atau duniawi, tetapi juga harus mendasarkan telah terpenuhinya kesejahteraan spiritual atau ukhrowi. Todaro dan Smith (2004), telah menjelaskan bahwa upaya untuk tercapainya kesejahteraan masyarakat secara material, duniawi dan spiritual dapat dilakukan dengan memperhatikan tiga hal yang mendasar yaitu: a. Tingkat Kebutuhan Dasar, yaitu peningkatan kemampuan dan pemerataan distribusi kebutuhan dasar individu seperti sandang, pangan, papan, kesehatan, dan perlindungan. b. Tingkat kehidupan, peningkatan tingkat kehidupan, tingkat pendapatan, pendidikan yang lebih baik dan peningkatan pendidikan. c. Memperluas skala ekonomi dari individu dan bangsa. Yaitu adanya pilihan pekerjaan yang lebih baik dari masyarakat yang lebih baik untuk meningkatkan kesejahteraan keluarga.

\section{Indikator Kesejahteraan}

Menurut Sukirno, kesejahteraan ialah aspek yang tidak hanya mementingkan tentang pola konsumsi tetapi pengembangan potensi atau kemampuan setiap manusia menjadi penting sebagai modal dalam mencapai kesejahteraan hidup. Oleh karena itu Sukirno membedakan kesejahteraan dalam tiga kelompok yaitu: a. Kelompok yang berusaha membandingkan tingkat kesejahteraan di dua negara dengan memperbaiki cara perhitungan pendapatan nasional. b. Kelompok yang berusaha menyusun penyesuaian pendapatan masyarakat dibandingkan dengan mempertimbangkan perbedaan tingkat harga negara. c. Kelompok yang berusaha untuk 
membandingkan berapa tingkat kesejahteraan setiap masyarakat pada suatu negara berdasarkan pada data yang tidak bersifat moneter. Tingkat kesejahteraan manusia dapat diukur dengan perhitungan fisik, dan non-fisik seperti tingkat konsumsi per-kapita, angka kriminalitas, angkatan kerja, tingkat ekonomi, dan akses di media masa. Selain itu, kesejahteraan masyarakat juga dapat diukur menggunakan IPM (Indeks Pembangunan Manusia) yang terdiri dari tiga gabungan dimensi yaitu dimensi umur, manusia terdidik dan standar hidup yang layak.

Menurut Badan Pusat Statistik, kesejahteraan adalah suatu keadaan dimana semua kebutuhan jasmaniah dan rohaniah rumah tangga tersebut dapat terpenuhi sesuai dengan tingkat hidup. Dan untuk mengukur tingkat kesejahteraan manusia, BPS (badan pusat statistik) memiliki beberapa indikator yang dapat digunakan yaitu sebagai berikut: 1) Pendapatan, pendapatan atau penghasilan adalah indikator yang dapat menunjukkan kesejahteraan masyarakat. Pendapatan yang dimaksud adalah penerimaan total kas yang diperoleh seseorang atau rumah tangga selama periode waktu tertentu (satu tahun).

Pendapatan terdiri dari penghasilan tenaga kerja, penghasilan atas milik (seperti sewa, bunga, dan deviden) serta tunjangan dari pemerintah. 2) Perumahan dan Pemukiman, keberadaan rumah sebagai tempat untuk bermukim menjadi kebutuhan dasar manusia, selain itu juga berfungsi yang sangat strategi perannya sebagai pusat pendidikan keluarga untuk meningkatkan kualitas sumber daya manusia yang akan datang. Selain itu, keberadaan rumah juga merupakan bagian dari kesehatan masyarakat, dimana rumah yang sehat dan nyaman adalah rumah yang mampu menunjang kondisi kesehatan tiap penghuninya. 3) Pendidikan, pendidikan merupakan hak asasi manusia dan hak setiap warga negara untuk dapat mengembangkan potensi dirinya melalui proses belajar. Setiap warga negara Indonesia berhak memperoleh pendidikan yang berkualitas sesuai dengan minat dan bakat yang dimiliki dengan tidak memandang perbedaan status ekonomi, sosial, suku, etnis, agama dan lokasi geografis. 5) Kesehatan, kesehatan merupakan salah satu ukuran kesejahteraan masyarakat yang sekaligus sebagai indikator dari berhasilnya program pembangunan.

Masyarakat yang sakit akan sulit memperjuangkan kesejahteraan bagi dirinya, sehingga berbagai upaya pembangunan di bidang kesehatan diharapkan dapat menjangkau semua lapisan masyarakat dan tidak ada diskriminatif dalam pelaksanaannya. Kesehatan menjadi indikator kesejahteraan dapat dilihat melalui mampu atau tidaknya masyarakat menjalani pengobatan di layanan kesehatan serta mampu untuk membiayai secara penuh obat yang dibutuhkan. Berdasarkan indikator-indikator kesejahteraan di atas maka proses pertumbuhan ekonomi merupakan pertumbuhan yang mendukung pembangunan manusia lebih berkualitas.

\section{Peran Usaha Mikro Kecil Dan Menengah Dalam Kesejahteraan Masyarakat}

Usaha mikro berperan penting untuk membangun perekonomian negara terkhususnya terhadap ekonomi masyarakat sekitar untuk memenuhi kebutuhan seharihari terlebih masa yang akan mendatang. Dalam hal ini peran usaha mikro sangat besar terhadap kegiatan ekonomi masyarakat. Usaha Mikro, Kecil dan Menengah (UMKM) mempunyai peran yang sangat penting dalam pertumbuhan perekonomian di Indonesia. Usaha Mikro, Kecil, dan Menengah eksistensinya telah terbukti mampu dalam perekonomian di Indonesia dalam berbagai keadaan.

Saat terjadi krisis moneter yang melanda Indonesia pada tahun 1998 dibandingkan perusahaan besar keberadaan usaha berskala kecil dan menengah relatif mampu bertahan. Hal ini karena usaha berskala kecil 
kebanyakan tidak terlalu tergantung pada modal besar atau pinjaman dari luar dalam mata uang asing. Sehingga, saat terjadi fluktuasi nilai tukar, perusahaan berskala besar yang kebanyakan menggunakan pinjaman dengan mata uang asing paling berpotensi mengalami dampak krisis.

Dalam perekonomian Indonesia Usaha Mikro, Kecil dan Menengah (UMKM) menurut Departemen Koperasi (2005) mempunyai peran yang penting, yaitu: (1) kedudukannya sebagai pemain utama dalam kegiatan ekonomi di berbagai sektor, (2) penyedia lapangan kerja yang terbesar, (3) pemain penting dalam pengembangan kegiatan ekonomi lokal dan pemberdayaan masyarakat, (4) pencipta pasar baru dan sumber inovasi, serta (5) sumbangannya dalam menjaga neraca pembayaran melalui kegiatan ekspor. Sudah terbukti bahwa keberadaan Usaha Kecil dan Menengah memegang peranan yang sangat penting dalam memajukan pertumbuhan perekonomian suatu negara.

Seperti yang terjadi di negara kita, sejak badai krisis ekonomi melanda yang terjadi pada tahun 1996, usaha kecil menengah keberadaannya hingga sekarang keberadaannya masih banyak dan mampu bertahan dan bahkan lebih berkembang. Meskipun saat terjadi krisis ekonomi mereka juga merasakan dampaknya dan sempat goyang, namun dengan adanya semangat dan jiwa kewirausahaan yang kuat secara perlahan-lahan mereka mampu bangkit dari keterpurukan serta bermanfaat bagi masyarakat maupun negara. Peran Usaha mikro, kecil, dan menengah (UMKM) sangat penting dalam memajukan perekonomian masyarakat Indonesia. Sehingga pemerintah Indonesia juga memandang pentingnya keberadaan dari para pelaku UMKM.

Terbukti, UMKM bersama dengan Koperasi yang telah diwadahi secara khusus di bawah naungan Kementerian Koperasi dan
UMKM. Sebagai wujud perhatian khusus yang tinggi diberikan oleh pemerintah kepada para pengusaha UMKM tersebut sebagai penyangga ekonomi rakyat kecil. Apalagi, keberadaan UMKM secara langsung mampu memberikan dampak terhadap peningkatan kehidupan masyarakat bawah. Ada tiga alasan utama suatu negara harus mendorong usaha kecil yang ada untuk terus berkembang. Alasan pertama adalah pada umumnya usaha kecil cenderung mampu menyerap dan menghasilkan tenaga kerja yang memiliki tingkat produktifitas kinerja. Kedua, dengan adanya investasi dan penerapan penggunaan teknologi seringkali mampu mencapai peningkatan produktivitasnya. Untuk alasan ketiga, usaha kecil ternyata memiliki tingkat fleksibilitas yang lebih unggul dibandingkan dengan perusahaan besar. Selain itu, ada tiga peran UMKM yang besar sumbangannya dalam kehidupan masyarakat kecil. Tiga peran tersebut adalah: a. Sebagai salah satu sarana untuk mengentaskan masyarakat dari kemiskinan. Hal ini dikarenakan tingginya angka penyerapan tenaga kerja oleh UMKM. b. sebagai sarana untuk lebih memeratakan tingkat perekonomian masyarakat kecil. UMKM keberadaannya tersebar di lokasi di berbagai tempat berbeda dengan perusahaan besar. Keberadaan UMKM yang tersebar di 34 provinsi mampu memperkecil jurang perbedaan tingkat ekonomi antara masyarakat miskin dengan kaya. c. Sebagai salah satu sumber pemasukan devisa bagi negara. Peran UMKM mampu memberikan devisa yang cukup besar sebagai salah satu penerimaan bagi negara. UMKM Indonesia saat ini dapat dikatakan sudah maju dan telah mampu memasuki pangsa pasar baik skala nasional, bahkan internasional.

Berdasarkan data dari Kementerian Koperasi dan UKM pada tahun 2017 menunjukkan para pelaku UMKM menyumbang devisa negara dari angkanya sangat tinggi, yaitu mencapai Rp 88,45 miliar. Angka ini 
jika dibandingkan tahun 2016 meningkat hingga mencapai delapan kali lipat. Peran penting UMKM mampu menumbuhkan perekonomian baik di kota-kota besar maupun di pedesaan. Berikut peran penting UMKM, yaitu: a. Memberikan pelayanan ekonomi secara luas; b. Meningkatkan pendapatan masyarakat, mendorong pertumbuhan ekonomi melalui proses pemerataan pendapatan untuk mewujudkan stabilitas nasional. c. Krisis moneter 1998, krisis 20082009, 96\% UMKM tetap bertahan.

UMKM apabila dibanding dengan usaha yang berskala lebih besar, mempunyai tingkat fleksibilitas yang tinggi, sehingga UMKM perlu didukung oleh informasi akurat dan mendapat perhatian khusus agar mendapatkan jaringan pasar yang luas sehingga perkembangan pelaku usaha kesil menengah dapat berkembang dan mampu bersaing. Perkembangan UMKM diharapkan memberikan kontribusi positif, yaitu: pelaku usaha dominan (99,9\%); menghasilkan PDB sebesar 59,08\% (Rp 4.869,57 triliun), dengan laju tulang punggung perekonomian nasional karena merupakan populasi pertumbuhan sebesar $6,4 \%$ per tahun; dari total ekspor nasional; Pembentukan Modal Tetap Bruto (PMTB) nasional sebesar 52,33\%; menyumbang volume ekspor mencapai 14,06\% (Rp 166,63 triliun) (Rp 830,9 triliun); secara geografis keberadaan UMKM tersebar di seluruh Indonesia dan tersebar di semua sektor. Memberikan layanan kebutuhan pokok yang dibutuhkan masyarakat; Multiplier effect-nya tinggi.

Merupakan alat untuk memeratakan pendapatan sehingga mampu mengurangi kesenjangan kesejahteraan di antara golongan masyarakat; sebagai wadah untuk penciptaan wirausaha muda yang baru; tidak banyak tergantung dengan komponen impor. Mampu menghemat devisa karena UMKM banyak menggunakan bahan baku dan sumber daya lokal yang mudah ditemukan dan tersedia di sekitar.

\section{PENUTUP}

\section{Simpulan}

Usaha mikro, kecil, dan menengah (UMKM) memiliki peran penting dalam meningkatkan perekonomian masyarakat sehingga mampu memperkecil jurang pemisah antara yang kaya dengan yang miskin. Perhatian pemerintah terhadap pentingnya peran dan keberadaan para usahawan UMKM dibuktikan dengan adanya wadah UMKM dan Koperasi berada di bawah Kementerian Koperasi dan UMKM. Perhatian yang tinggi tersebut diberikan kepada para pelaku UMKM tersebut sebagai wujud penghargaan pemerintah yang mampu menopang keberadaan ekonomi rakyat kecil dan berdampak langsung terhadap tingkat kehidupan masyarakat kalangan bawah sehingga kesejahteraan masyarakat dapat terus meningkat. Selain itu, peran UMKM juga sangat penting dalam kehidupan masyarakat kecil yaitu: a. sebagai salah satu sarana untuk mengentaskan masyarakat dari kemiskinan. b. sarana untuk meratakan tingkat perekonomian rakyat kecil. c. Memberikan pemasukan devisa bagi negara.

\section{Saran}

Saran yang dapat di ajukan adalah: a) pemerintah secara terus menerus mengadakan pembinaan dan pelatihan untuk tumbuhnya wirausaha-wirausaha muda yang baru dan berkembangnya UMKM yang sudah ada untuk meningkatkan kesejahteraan masyarakat; b) Memberikan fasilitas kemudahan akses dan persyaratan untuk mendapatkan dan meningkatkan permodalan; c) Untuk pelaku UMKM secara berkelanjutan berusaha untuk meningkatkan kompetensinya baik secara mandiri maupun fasilitas dari pemerintah sehingga usahanya terus semakin berkembang baik dari sisi permodalan maupun variasi komoditasnya. 


\section{DAFTAR PUSTAKA}

Bintarto. (1989). Interaksi Desa-Kota dan Permasalahannya. Ghalia Indonesia. Jakarta.

Dayintapinasthika, "Usaha Kecil Menengah (UKM)", (Online), tersedia di https://dayintapinasthika.wordpress. com/2011/04/12/usaha-kecilmenengah ukm/?_e_pi_=7\%2CPAG_ ID10\%2C5083335373 (12 November 2018).

Departemen Koperasi 2008 tersedia di : www.depkop.go.id. Situs Resmi Departemen Koperasi. (Diakses tanggal 28 Desember 2018).

Husada Putra, Adnan. (2016). Peran UMKM dalam Pembangunan dan Kesejahteraan Masyarakat Kabupaten Blora. Jurnal Analisa Sosiologi, 5(2): 40-52.

Lembaga Pengembangan Perbankan Indonesia dan BI. (2015). Profil Bisnis Usaha Mikro, Kecil Dan Menengah (UMKM).

Rahmini Suci, Yuli. (2017). Perkembangan UMKM (Usaha Mikro Kecil Dan Menengah) Di Indonesia, Jurnal Ilmiah Cano Ekonomos, 6.
Sukirno, Sadono. (2010). Makro Ekonomi, Teori Pengantar. Penerbit PT. Raja Grafindo Persada, Jakarta.

Tulus T.H. Tambunan. (2009). UMKM di Indonesia, Ghalia Indonesia, Bogor.

Triyaningsih. (2012). Strategi Pemasaran Usaha Kecil dan Menengah, Jurnal Ekonomi dan Kewirausahaan Vol. 12, No. 1, April 2012 : 44-45.

Todaro, Michael P. dan Stephen C. Smith. (2004). Pembangunan Ekonomi di Dunia Ketiga, Edisi ke delapan. Jakarta: Erlangga.

Undang-Undang Nomor tahun 2008 tentang UMKM.

Undang-undang No. 11 Tahun 2009, tentang Kesejahteraan Masyarakat.

Wahyuningsih. Sri. (2009). Peranan UKM Dalam Perekonomian Indonesia. Mediagro 5: 1-14. 